Jean Moore ${ }^{1}$

\title{
HEALTH PROFESSIONS REGULATION IN THE UNITED STATES*
}

Regulação das profissões de saúde nos Estados Unidos

${ }^{1}$ New York Center for Health Workforce Studies. New York, United States.

Correspondence: jmoore@albany.edu

Received: 09/01/2016. Approved: 10/05/2017.

\footnotetext{
*Original paper developed in the scope of the research "Regulation of health professions in Brazil: Legal and institutional mapping, identification of points of articulation and disarticulation and formulation of proposals for regulatory harmonization", carried out by the Center of Study and Research in Health Law (Cepedisa) 2016.
} 


\section{ABSTRACT}

The regulation of health professions in the United States is a primary responsibility of states. The structure and content of the specific regulations of each state impact the provision of health services, affecting costs, quality and access. There is concern that current state-based and profession-specific regulatory structures cannot serve as a basis for the innovations the health workforce needs for health reform. This paper reviews aspects of state-based health professions regulations that limit the effective use of health workers and also one of its key advantages: their ability to provide local solutions to address access problems. The paper describes elements that generate changes in the demand for health services and health care providers. Finally, strategies are recommended to improve decision-making related to practice including: standardization of practice scopes between different states; permanent updating of specific acts of professional practice in each state, in accordance with the evolution of professional competencies; use of the best evidence to authorize new professions or expand the scope of practice of the existing ones and, when this evidence does not exist, to promote programs to test new modalities of work. Taking into account the pace of changes in the health system in the United States, there is a growing urgency for reforms to ensure adequate size and training of the workforce for the future.

\section{Keywords}

Health in United States; Health Workforce; Regulation.

\section{RESUMO}

A regulação das profissões de saúde nos Estados Unidos é uma responsabilidade primária dos estados. A estrutura e conteúdo das regulações específicas de cada estado impactam a prestação de serviços de saúde, afetando os custos, a qualidade e o acesso. Existe uma preocupação que as atuais estruturas regulatórias com base estadual e específicas por profissão não poderão servir de base para as inovações que a forca de trabalho em saúde necessita para a reforma do sistema de saúde. Este artigo revisa aspectos da regulação de profissões de saúde de base estadual que limitam o uso efetivo dos trabalhadores de saúde e também uma de suas principais vantagens: sua capacidade de dar fundamento a soluções locais para enfrentar problemas de acesso. Descrevem-se os elementos geradores das mudanças na demanda por serviços de saúde e por prestadores de saúde. Por último, recomendam-se estratégias para melhorar as decisões em relação à práticas, incluindo: padronização de escopos de práticas entre diferentes estados; atualização permanente de atos de prática profissional específicos de cada estado, de acordo com a evolução das competências profissionais; uso das melhores evidências para autorizar novas profissões ou expandir o escopo das práticas já existentes e, quando esta evidência não existir, promover programas para testar novas modalidades de trabalho. Levando em conta o ritmo das transformações do sistema de saúde nos Estados Unidos, existe uma urgência crescente para que as reformas assegurem uma força de trabalho adequadamente dimensionada e treinada para o futuro.

\section{Palavras-Chave}

Regulação; Saúde nos Estados Unidos; Trabalhadores da Saúde. 


\section{Introduction}

In the U.S., states are primarily responsible for the regulation of health professions. The structure and content of state-specific health professions regulation has significant impacts on the delivery of health care services. This is particularly important given that health reform initiatives are designed to improve population health through the provision of accessible, high quality, and affordable basic health services. There is concern that existing state-based, profession-specific regulatory structures cannot easily support the workforce innovations necessary for health reform. Aspects of the current system that constrain the effective and efficient use of the health workforce include mismatches between professional competence and legal scopes of practice, lack of consistency in legal scopes of practice across states, limited flexibility to support overlap in scopes of practice across professions, and the slow and adversarial process for changing scope of practice rules ${ }^{1}$.

\section{Health professions regulation and health reform}

The U.S. health care delivery system is market-based, comprised of many private and public payers, including federal and state government. Consequently, it lacks a single set of consistent policies to guide the system and is frequently characterized by a great deal of fragmentation that produce inefficiencies and poor health outcomes ${ }^{2}$. Health reform is having substantial impacts on the U.S. health care delivery system, through a rapid shift in focus to primary care, prevention, and population health. Health care reimbursement is also changing, moving away from fee-for-service and toward value-based payment. Increasingly, health care providers receive incentives for keeping people healthy and face penalties for poor outcomes, such as avoidable hospital readmissions. Providers are challenged to deliver high quality and accessible services to a growing number of newly insured patients as cost-effectively as possible. New models of care are emerging, including accountable care organizations and patient centered medical homes. Central to these models are multidisciplinary care teams, that can potentially improve patient outcomes and promote optimal use of available resources ${ }^{3}$. Team configurations are based on the needs of the patient population, and the size and type of primary care practice. Teams can include, among others, physicians, nurse practitioners, physician assistants, registered nurses, social workers, dieticians, licensed practical nurses, medical

\footnotetext{
${ }^{1}$ DOWER, C.; MOORE, J.; LANGELIER, M. It is time to restructure health professions scope-of-practice regulations to remove barriers to care. Health Affairs, v. 32, n. 11, 1971-1976, Nov. 2013. doi:10.1377/ hlthaff.2013.0537.

${ }^{2} \mathrm{SHIH}$, A.; DAVIS, K.; SCHOENBAUM S.C.; GAUTHIER A.; NUZUM, R.; MCCARTHY, D. Organizing the U.S. Health care delivery system for high performance. Aug. 2008. Available at: <http://ts-si.org/files/Shih_ Organizing_8-4-08.pdf>. Accessed: Aug. 22, 2016.

${ }^{3} \mathrm{CHADI}, \mathrm{N}$. Breaking the scope-of-practice taboo: where multidisciplinary rhymes with cost-efficiency. McGill Journal of Medicine, v. 13, n. 2, p. 44, 2011.
} 
assistants, and community health workers ${ }^{4}$. The most effective teams are characterized by high levels of cohesiveness and shared responsibility, which can improve the efficiency and accessibility of health care services ${ }^{5},{ }^{6}$. However, most state-based health professions regulatory structures lack the flexibility to fully support professionals working collaboratively in team-based models of care. While protection of the public through mindful regulations is a critically important objective, state regulatory processes and policies may result in overly restrictive or proscriptive practice standards that can impede delivery of care, increase the cost of services, and fail to fully use the abilities of the available health workforce ${ }^{7}$.

\section{What are the issues with a state-based system?}

State-based laws and regulations define legal scopes of practice for health professionals within a state. Profession-specific scope of practice laws generally describe the health services that can be legally offered by a health professional (including controlled acts) and the circumstances under which these services may be provided (the context for professional practice). They typically include the requirements for a health professional to practice in a state, including qualifying education and training, licensure, and applicable supervisory requirements. In addition, they often specify the composition and authority of the regulatory board that oversees the profession as well as disciplinary procedures and actions.

There are a number of issues associated with a state-based approach to health professions regulation. They include:

(i) Mismatches between professional competence (i.e., what a health professional is trained and competent to do) and legal scope of practice, (i.e., what a health professional is legally allowed to do in a given state). The term "scope of practice" generally describes what type of services a member of a health profession can provide. However, it is important to distinguish between "professional" scope of practice and "legal" scope of practice, described above. Professional scope of practice, often referred to as professional competence, describes the services that a health care professional is trained and competent to perform.

\footnotetext{
${ }^{4}$ BODENHEIMER, T. Building teams in primary care: lessons from 15 case studies. California Health Care Foundation, July 2007. Available at: <https://www.chcf.org/wp-content/uploads/2017/12/PDF-BuildingTe amsInPrimaryCareCaseStudies.pdf >. Accessed: Aug. 15, 2016.

IINTERPROFESSIONAL Education Collaborative Expert Panel. Core competencies for interprofessional collaborative practice: Report of an expert panel. Washington, D.C.: Interprofessional Education Collaborative, 2011. Available at: <https://www.aamc.org/download/ 186750/data/core_competencies.pdf>. Accessed: Aug. 15, 2016.

${ }^{6}$ MITCHELL, P. et al. Core principles \& values of effective team-based health care. Discussion Paper, Institute of Medicine, Washington, DC, 2012. Available at: <https://www.nationalahec.org/pdfs/VSRT-Team-BasedCare-Principles-Values.pdf>. Accessed: Aug. 15, 2016.

${ }^{7}$ RICKETTS, T.C.; FRAHER, E.P. Reconfiguring health workforce policy so that education, training, and actual delivery of care are closely connected. Health Affairs, v. 32, n. 11, p. 1874-1880, Nov. 2013. doi:10.1377/ hlthaff.2013.0531.
} 
Professional competence evolves over time as health professions integrate new developments into the clinical practice of the profession, typically expanding both the body of knowledge and skills for that profession. While legal scope of practice and professional competence typically overlap, the amount of overlap varies by profession and by state.

Most health professionals in the U.S. train in nationally accredited educational programs that use a standard curriculum, and subsequently complete national or regional competency testing to obtain certification to practice. Despite national standards for training and certification, some states limit health professionals' ability to practice to the full scope of their demonstrated professional competency.

One example of an effort to better align professional competence with legal scope of practice has been the move to allow pharmacists in all 50 states to administer influenza vaccines. It took over a decade to accomplish this in all states, and resulted in immunizations becoming more widely available to the U.S. population ${ }^{8,9}$.

(ii) The mismatches cited above contribute to state-to-state variation in legal scope of practice for many health professions. This variation is contingent on practice location rather than on a health professional's skills and competencies. For example, nurse practitioners' ability to safely diagnose, treat, and prescribe has been well documented in the research literature ${ }^{10}$. However, only half of states have granted nurse practitioners full authority to provide such services, and the remaining states place limits on their practice ${ }^{11}$. Since health professionals must be licensed in each state of practice, mobility may be limited for professions with state-to-state scope of practice variation. This lack of mobility can contribute to workforce inefficiencies and, at the same time, limit access to needed care, including the provision of telehealth and telemedicine services across state boundaries ${ }^{12,13}$.

\footnotetext{
${ }^{8}$ TERRIE, Y.C. Vaccinations: the expanding role of pharmacists. Pharmacy Times, Jan. 14, 2010. Available at: <http://www.pharmacytimes.com/publications/issue/2010/January2010/FeatureFocusVaccinations-0110>. Accessed: Aug. 15, 2016.

${ }^{9}$ MCCONEGHY, K.W.; WING, C. A national examination of pharmacy-based immunization statutes and their association with influenza vaccinations and preventive health. Vaccine, v. 34, n. 30, p. 3463-3468, 2016. doi:10.1016/j.vaccine.2016.04.076.

${ }^{10}$ NEWHOUSE, R. et al. Advanced practice nurse outcomes 1990-2008: a systematic review. Nursing Economics, v. 29, n. 5, p. 230-250, 2011.

${ }^{11}$ PEARSON, L. Nurse practitioner's business practice and legal guide, fifth edition. The Pearson Report. Available at: <http://nursing.jbpub.com/pearsonreport/Login.aspx?ref=/pearsonreport/default.aspx>. Accessed: Aug. 15, 2016.

${ }^{12}$ ROWTHORN, V.; HOFFMAN, D. Legal impediments to the diffusion of telemedicine. Journal of Health Care Law and Policy, v. 14, n. 1, 2011.

${ }^{13}$ LEROUGE, C.; GARFIELD, M.J. Crossing the telemedicine chasm: have the U.S. barriers to widespread adoption of telemedicine been significantly reduced? †. Int J Environ Res Public Health, v. 10, n. 12, p. 6472-6484, Dec. 2013. Available at: <http://www.ncbi.nlm.nih.gov/pmc/articles/PMC3881125/>. Accessed: Aug. 15, 2016. 10.3390/ijerph10126472.
} 
However, state-to-state scope of practice variation does provide important research opportunities. On the issue of access, researchers have found that states with the least restrictive scope of practice for nurse practitioners experienced the largest increase in the number of patients seen by these professionals in primary care practices over recent years ${ }^{14}$. Another study found that the frequency of routine checkups increased and quality of health care improved in states that allow nurse practitioners to practice more autonomously ${ }^{15}$. These are especially important findings in light of the growing demand for primary health care services under health reform initiatives.

(iii) Another issue associated with state-based health professions regulation systems is the lack of ability to support overlapping scopes of practice. There is growing recognition that overlapping practice acts-those that enable different professions to provide the same services-should be normative ${ }^{16}$. This shift in thinking recognizes the unique contributions of various professions, with different philosophical approaches to health service delivery but equal competence to treat patients, and acknowledges collaborative roles in team-based models of care. There would be less resistance to overlapping scopes of practice if there were more opportunities for interdisciplinary education and training, which increases awareness that individuals from different health professions are capable of safely performing the same tasks. Scope overlap can be even more challenging when it involves delegation. Lack of clarity and consistency in regulations about delegation and liability adversely impact efforts to increase scope overlap, including, for example, allowing home health aides, supervised by registered nurses, to administer medication to their patients.

(iv)Changing state-specific legal scope of practice for a health profession often requires state-level legislative and/or regulatory action, which tends to be slow, adversarial, and expensive, typically involving two professions: an incumbent profession and an emerging profession. Incumbent professions, often with greater resources for lobbying and advocacy, can overpower emerging professions with more modest political means, sometimes despite clear evidence of the safety and quality of services provided by the emerging profession. For example, a number of states have considered authorizing advanced practice dental hygienists who, with additional training, can provide basic restorative oral health services, but only a handful of states have succeeded. Frequently,

\footnotetext{
${ }^{14}$ KUO, Y.; LORESTO, F.L.; ROUNDS, L.R.; GOODWIN, J.S. States with the least restrictive regulations experienced the largest increase in patients seen by nurse practitioners. Health Affairs, v. 32, n. 7, p. 1236-1243, Jul. 2013. 10.1377/hlthaff.2013.0072.

${ }^{15}$ TRACZYNSKI, J.; UDALOVA, V. Nurse practitioner independence, health care utilization, and health outcomes. Paper presented at: Midwest Health Economics Conference. Madison, WI, 2013. Available at: <http://www2.hawaii.edu/ jtraczyn/paperdraft_050414_ASHE.pdf>. Accessed: Aug. 15, 2016.

${ }^{16}$ NATIONAL COUNCIL OF STATE BOARDS OF NURSING. Changes in healthcare professions' scope of practice: legislative considerations. Report, 2009. Available at: <https://www.ncsbn.org/ScopeofPractice_09.pdf>. Accessed: Aug. 15, 2016.
} 
multiple campaigns are waged before a change is made. The first attempt to pass a law recognizing dental hygiene therapists in Maine in 2014 failed, but succeeded in the following legislative session. These adversarial processes can also contribute to animosity between professionals, who must work together regardless of legislative outcomes. The team-based practice models supported by health reform are harder to implement when members of one profession see members of another as the opposition.

One important advantage of state-based health professions regulation is its ability to support local solutions to expand access to needed health services. For example, the state of Minnesota, concerned about limited access to oral health services for the state's low-income populations, recognized advanced dental therapists (ADTs) in 2009. ADTs are allowed to work under general supervision and at least half of their patients must be underserved. Initial assessments of ADT impacts find that patients served by ADTs experienced reduced wait times and travel times as well as improved patient satisfaction scores. ADT employers reported cost savings and improved oral health team productivity ${ }^{17,18}$.

\section{Drivers of change in demand for health services and health workers}

There are many drivers of change in demand for health services and health workers. They include, among others, public policy, technology, and consumer preference.

Currently, health reform is one of the most significant public policy drivers influencing the health care delivery system and its workforce. As demand for primary care services grows, regulatory barriers to practice for NPs, for example, could result in lengthy wait times and delays in receiving needed services. Using existing workforce more expansively within their practice competencies may help meet growing demand for health services in the coming years ${ }^{19}$.

Another public policy driver is concern about persistent health disparities that exerts pressure on the health care delivery system generally and on the health workforce specifically. Significant disparities in health status and access to health services related to geography, gender, race, and ethnicity are a major challenge

\footnotetext{
${ }^{17}$ BHASKARA, S. Early impacts of dental therapists in Minnesota on access to care. Paper presented at: $142^{\text {nd }}$ Annual APHA Annual Meeting and Exposition, New Orleans, LA, Nov. 2014. Available at: <https://apha. confex.com/apha/142am/webprogram/Paper298793.html>. Accessed: Aug. 22, 2016.

${ }^{18}$ THE PEW CHARITABLE TRUSTS. Expanding the dental team: increasing access to care in public settings. Report, June 2014. Available at: <http://www.pewtrusts.org/ /media/assets/2014/06/27/expanding dental_case_studies_report.pdf>. Accessed: Aug. 22, 2016.

${ }^{19}$ HAIN, D.; FLECK, L. Barriers to NP practice that impact healthcare redesign. The Online Journal of Issues in Nursing, v. 19, n. 2, May 31, 2014. Available at: <http://www.nursingworld.org/MainMenuCategories/ ANAMarketplace/ANAPeriodicals/OJIN/TableofContents/Vol-19-2014/No2-May-2014/Barriers-to-NPPractice.html>. Accessed: Aug. 15, 2016.
} 
in health care today ${ }^{20}$. The health workforce has the potential to play key roles in reducing these disparities. The use of community health workers is one strategy to address disparate health outcomes. Community health workers, who are often trusted members of the communities they serve, can work in culturally sensitive ways to link patients to providers and public health programs to address heart disease, stroke, asthma, diabetes, cancer, and other chronic diseases ${ }^{21}$.

Technological innovation in health care can either simplify processes, reducing the needed training to provide a service, or increase complexity and require the use of more highly trained specialists. In addition, technology has enabled telehealth initiatives, which have raised new scope of practice issues, especially when the patient and the health care provider are in different states. There is growing recognition of the value of standardizing state practice acts or adopting uniform telehealth laws to meet the needs of patients, health professionals, and employers who are operating in a virtual interstate market that is limited by state-based regulation ${ }^{22}$.

Consumer preference drives change, as evidenced by the growing popularity of retail clinics ${ }^{23}$, which act as an accessible, cost-effective way to meet basic health care needs. These clinics, usually staffed by NPs, have been shown to reduce costs for episodes of care. An analysis of multistate insurance claims data for episodes of care that included retail clinic use found that costs for care were lower in states where NPs practiced more independently ${ }^{24}$. In addition, consumer demand for complementary and alternative health care approaches, including acupuncture, massage therapy, and yoga, has been steadily growing. The 2012 National Health Interview Survey found that nearly 60 million Americans reported spending over $\$ 30$ billion out-of-pocket annually on complementary and alternative health care ${ }^{25}$. This has resulted in an increasing number of states recognizing naturopathic physicians, homeopaths, acupuncturists, and massage therapists.

\section{Strategies to strengthen scope of practice decision-making}

As states consider scope of practice changes for many health professions, they must assess the impacts of these proposed changes on the safety and quality of

\footnotetext{
${ }^{20}$ SCHROEDER, S.A. We can do better - improving the health of the American people. New England Journal of Medicine, v. 357, n. 12, p. 1221-1228, 2007. doi:10.1056/nejmsa073350.

${ }^{21}$ ROSENTHAL, E.L. et al. Community health workers: part of the solution. Health Affairs, v. 29, n. 7, p. 1338-1342, 2010. 10.1377/hlthaff.2010.0081.

${ }^{22}$ LEROUGE, C.; GARFIELD, M.J. op. cit., p. 6472-6484.

${ }^{23}$ ZAMOSKY, L. What retail clinic growth can teach physicians about patient demand. Medical Economics, Jan. 8, 2014 Available at: <http://www.medicaleconomics.com/modern-medicine-feature-articles/what-retailclinic-growth-can-teach-physicians-about-patient-demand>. Accessed: Aug. 15, 2016.

${ }^{24}$ SPETZ, J.; PARENTE, S.T.; TOWN, R.J.; BAZARKO D. Scope-of-practice laws for nurse practitioners limit cost savings that can be achieved in retail clinics. Health Affairs, v. 32, n. 11, p. 1977-1984, 2013.10.1377/ hlthaff.2013.0544.

${ }^{25}$ AMERICANS spend $\$ 30$ Billion a year out-of-pocket on complementary health approaches. National Center for Complementary and Integrative Health, June 22, 2016. Available at: <https://nccih.nih.gov/research/ results/spotlight/americans-spend-billions/>. Accessed: Aug. 15, 2016.
} 
health services provided in their states. There are a number of strategies that could improve both the process and content of scope of practice decision-making:

(i) Standardize scopes of practice for health professionals across states, based on professional competence ${ }^{26}$, to enable efficient and effective delivery of services unencumbered by state boundaries.

(ii) Routinely update state-specific health professional practice acts allowing health professions to demonstrate their increasing competence and permit them to practice to the full extent of their education and training. This could support both new and emerging roles as well as the scope overlap needed for effective team-based care $^{27}$.

(iii) Increase the amount of consumer input to inform scope of practice decision-making.

(iv) Use the best available evidence to make decisions about authorizing new professions or expanding scope of practice for existing professions ${ }^{28}$.

(v) Create opportunities to test new workforce strategies for health service delivery in time-limited pilot projects sponsored by states, such as California's Health Workforce Pilot Project program ${ }^{29}$. Rigorous outcomes evaluations of projects are essential to inform regulatory decision making in the sponsoring state and in other states.

\section{Conclusion}

Efforts to transform the health care delivery system in the U.S. and to improve population heath require a workforce that is capable of assuming new roles and responsibilities, particularly in emerging models of care. Collectively, the health workforce is key to states' efforts to provide high quality, cost-effective care to the growing number of Americans seeking primary care services. Given the pace of health care delivery system transformation, there is a growing urgency for the regulatory reform needed to assure an adequately sized and trained health workforce for the future.

\footnotetext{
${ }^{26}$ LEBUHN, R.; SWANKIN, D. Reforming scopes of practice: a white paper. Citizen Advocacy Center White Paper, jul. 2010. Available at: <https://www.ncsbn.org/ReformingScopesofPractice-WhitePaper.pdf>. Accessed: Aug. 15, 2016.

${ }^{27}$ NATIONAL COUNCIL OF STATE BOARDS OF NURSING. Changes in healthcare professions' scope of practice: legislative considerations, cit.

${ }^{28}$ DOWER, C.; CHRISTIAN, S.; O'NEIL, E. Promising scope of practice models for the health professions. Healthforce Center at UCSF Report, 2007. Available at: <https://healthforce.ucsf.edu/sites/healthforce. ucsf.edu/files/publication-pdf/6.\%202007-12_Promising_Scope_of_Practice_Models_for_the_Health_ Professions.pdf>. Accessed: Aug. 15, 2016.

${ }^{29}$ WIDES, C.; DOWER, C. A review of California Office of Statewide Health Planning and Development, Health Workforce Pilot Projects Program 1973-2007. Healthforce Center at UCSF Report, May 2010. Available at: <https://healthforce.ucsf.edu/sites/healthforce.ucsf.edu/files/publication-pdf/7.\%202010-05_A_Review_ of_OSHPD_Health_Workforce_Pilot_Projects_Program_1973_to_2007.pdf >. Accessed: Aug. 5, 2016.
} 


\section{References}

AMERICANS spend $\$ 30$ Billion a year out-of-pocket on complementary health approaches. National Center for Complementary and Integrative Health, June 22, 2016. Available at: <https://nccih.nih.gov/research/results/spotlight/americans-spendbillions/>. Accessed: Aug. 15, 2016.

BHASKARA, S. Early impacts of dental therapists in Minnesota on access to care. Paper presented at: $142^{\text {nd }}$ Annual APHA Annual Meeting and Exposition, New Orleans, LA, Nov. 2014. Available at: <https://apha.confex.com/apha/142am/webprogram/Paper298793.html $>$. Accessed: Aug. 22, 2016.

BODENHEIMER, T. Building teams in primary care: lessons from 15 case studies. California Health Care Foundation, July 2007. Available at: <https://www.chcf.org/ wp-content/uploads/2017/12/PDF-BuildingTeamsInPrimaryCareCaseStudies.pdf $>$. Accessed: Aug. 15, 2016.

CHADI, N. Breaking the scope-of-practice taboo: where multidisciplinary rhymes with costefficiency. McGill Journal of Medicine, v. 13, n. 2, p. 44, 2011.

DOWER, C.; CHRISTIAN, S.; O’NEIL, E. Promising scope of practice models for the health professions. Healthforce Center at UCSF Report, 2007. Available at: <https:// healthforce.ucsf.edu/sites/healthforce.ucsf.edu/files/publication-pdf/6.\%202007-12_ Promising_Scope_of_Practice_Models_for_the_Health_Professions.pdf $>$. Accessed: Aug. 15, 2016.

; MOORE, J.; LANGELIER, M. It is time to restructure health professions scope-ofpractice regulations to remove barriers to care. Health Affairs, v. 32, n. 11, 1971-1976, Nov. 2013. doi:10.1377/hlthaff.2013.0537.

HAIN, D.; FLECK, L. Barriers to NP practice that impact healthcare redesign. The Online Journal of Issues in Nursing, v. 19, n. 2, May 31, 2014. Available at: <http://www.nursingworld. org/MainMenuCategories/ANAMarketplace/ANAPeriodicals/OJIN/TableofContents/Vol-192014/No2-May-2014/Barriers-to-NP-Practice.html>. Accessed: Aug. 15, 2016.

INTERPROFESSIONAL Education Collaborative Expert Panel. Core competencies for interprofessional collaborative practice: Report of an expert panel. Washington, D.C.: Interprofessional Education Collaborative, 2011. Available at: <https://www.aamc.org/ download/ 186750/data/core_competencies.pdf>. Accessed: Aug. 15, 2016.

KUO, Y.; LORESTO, F.L.; ROUNDS, L.R.; GOODWIN, J. S. States with the least restrictive regulations experienced the largest increase in patients seen by nurse practitioners. Health Affairs, v. 32, n. 7, p. 1236-1243, Jul. 2013. 10.1377/hlthaff.2013.0072.

LEBUHN, R.; SWANKIN, D. Reforming scopes of practice: a white paper. Citizen Advocacy Center White Paper, Jul. 2010. Available at: <https://www.ncsbn.org/ ReformingScopesofPractice-WhitePaper.pdf $>$. Accessed: Aug. 15, 2016. 
LEROUGE, C.; GARFIELD, M.J. Crossing the telemedicine chasm: have the U.S. barriers to widespread adoption of telemedicine been significantly reduced?. Int J Environ Res Public Health, v. 10, n. 12, p. 6472-6484, Dec. 2013. Available at: <http://www.ncbi.nlm.nih.gov/ pmc/articles/PMC3881125/>. Accessed: Aug. 15, 2016. 10.3390/ijerph10126472.

MCCONEGHY, K.W.; WING, C. A national examination of pharmacy-based immunization statutes and their association with influenza vaccinations and preventive health. Vaccine, v. 34, n. 30, p. 3463-3468, 2016. doi:10.1016/j.vaccine.2016.04.076.

MITCHELL, P. et al. Core principles \& values of effective team-based health care. Discussion Paper, Institute of Medicine, Washington, DC, 2012. Available at: $<$ https://www.nationalahec. org/pdfs/VSRT-Team-Based-Care-Principles-Values.pdf>. Accessed: Aug. 15, 2016.

NATIONAL COUNCIL OF STATE BOARDS OF NURSING. Changes in healthcare professions' scope of practice: legislative considerations. Report, 2009. Available at: $<\mathrm{https}: / /$ www.ncsbn.org/ScopeofPractice_09.pdf>. Accessed: Aug. 15, 2016.

NEWHOUSE, R. et al. Advanced practice nurse outcomes 1990-2008: a systematic review. Nursing Economics, v. 29, n. 5, p. 230-250, 2011.

PEARSON, L. Nurse practitioner's business practice and legal guide, fifth edition. The Pearson Report. Available at: <http://nursing.jbpub.com/pearsonreport/Login.aspx?ref=/ pearsonreport/default.aspx>. Accessed: Aug. 15, 2016.

THE PEW CHARITABLE TRUSTS. Expanding the dental team: increasing access to care in public settings. Report, June 2014. Available at: <http://www.pewtrusts.org/ /media/ assets/2014/06/27/expanding_dental_case_studies_report.pdf $>$. Accessed: Aug. 22, 2016.

RICKETTS, T.C.; FRAHER, E.P. Reconfiguring health workforce policy so that education, training, and actual delivery of care are closely connected. Health Affairs, v. 32, n. 11, p. 18741880, Nov. 2013. doi:10.1377/hlthaff.2013.0531.

ROSENTHAL, E.L. et al. Community health workers: part of the solution. Health Affairs, v. 29, n. 7, p. 1338-1342, 2010. 10.1377/hlthaff.2010.0081.

ROWTHORN, V.; HOFFMAN, D. Legal impediments to the diffusion of telemedicine. Journal of Health Care Law and Policy, v. 14, n. 1, 2011.

SCHROEDER, S.A. We can do better - improving the health of the American people. New England Journal of Medicine, v. 357, n. 12, p. 1221-1228, 2007. doi:10.1056/nejmsa073350.

SHIH, A.; DAVIS, K.; SCHOENBAUM S.C.; GAUTHIER A.; NUZUM, R.; MCCARTHY, D. Organizing the U.S. Health care delivery system for high performance. Aug. 2008. Available at: $<$ http://ts-si.org/files/Shih_Organizing_8-4-08.pdf>. Accessed: Aug. 22, 2016.

SPETZ, J.; PARENTE, S.T.; TOWN, R.J.; BAZARKO D. Scope-of-practice laws for nurse practitioners limit cost savings that can be achieved in retail clinics. Health Affairs, v. 32, n. 11, p. 1977-1984, 2013.10.1377/hlthaff.2013.0544. 
TERRIE, Y.C. Vaccinations: the expanding role of pharmacists. Pharmacy Times, Jan. 14, 2010. Available at: <http://www.pharmacytimes.com/publications/issue/2010/January2010/ FeatureFocusVaccinations-0110>. Accessed: Aug. 15, 2016.

TRACZYNSKI, J.; UDALOVA, V. Nurse practitioner independence, health care utilization, and health outcomes. Paper presented at: Midwest Health Economics Conference. Madison, WI, 2013. Available at: <http://www2.hawaii.edu/ jtraczyn/paperdraft_050414_ASHE.pdf >. Accessed: Aug. 15, 2016.

WIDES, C.; DOWER, C. A review of California Office of Statewide Health Planning and Development, Health Workforce Pilot Projects Program 1973-2007. Healthforce Center at UCSF Report, May 2010. Available at: <https://healthforce.ucsf.edu/sites/healthforce.ucsf. edu/files/publication-pdf/7.\%202010-05_A_Review_of_OSHPD_Health_Workforce_Pilot_ Projects_Program_1973_to_2007.pdf>.Accessed: August 15, 2016.

ZAMOSKY, L. What retail clinic growth can teach physicians about patient demand. Medical Economics, Jan. 8, 2014 Available at: <http://www.medicaleconomics.com/modern-medicinefeature-articles/what-retail-clinic-growth-can-teach-physicians-about-patient-demand $>$. Accessed: Aug. 15, 2016.

Jean Moore - Director of the New York Center for Health Workforce Studies. New York, United States of America. E-mail: jmoore@albany.edu 